\title{
Physiological Evaluation of Nitrogen Use Efficiency and Yield Attributes in Rice (Oryza sativa L.) Genotypes under Different Nitrogen Levels
}

\author{
N. Kumar, B. MathPal, A. SHARma, A. SHUKLA, D. SHANKHDHAR \\ and S.C. SHANKHDHAR*
}

Department of Plant Physiology, College of Basic Sciences and Humanities, G. B. Pant University of Agriculture and Technology Pantnagar-263145, U. S. Nagar, Uttarakhand, India

(Received 1 March 2014; Accepted 20 May 2014;

Communicated by J. Kubat)

\begin{abstract}
Nitrogen use efficiency, more specifically physiological nitrogen use efficiency depends primarily on management of $\mathrm{N}$, one of the major essential nutrients. It is required in increased agricultural production and may possibly cause soil toxicity if fed in excess. Rate of $\mathrm{N}$ fertilizer application in fertile agricultural field and improved productivity in sterile soils require the improvement of NUE. A field experiment was therefore conducted to evaluate the effect of different $\mathrm{N}$ levels $\left(\mathrm{N}_{0}, \mathrm{~N}_{50}, \mathrm{~N}_{100}\right.$ and $\left.\mathrm{N}_{200}\right)$ on rice genotypes. Vegetative plant growth was found to be reduced under $\mathrm{N}_{0}$ while improved at $\mathrm{N}_{200}$ level. Among the genotypes, highest PNUE (34.94) and correspondingly higher yield ( 7.15 ton ha $\left.{ }^{-1}\right)$ was observed for Krishna Hamsa. The other traits viz. plant height, no. of productive tillers and LAI exhibited higher values for Krishna Hamsa as well. Hence these can be utilized as physiological markers for the selection of rice genotypes efficient in $\mathrm{N}$ use.
\end{abstract}

Keywords: nitrogen, rice, PNUE, ANUE

Abbreviations: N - Nitrogen, NUE - Nitrogen Use Efficiency, PNUE - Physiological Nitrogen Use Efficiency, ANUE - Agronomical Nitrogen Use Efficiency, LAI - Leaf Area Index, GHI - Grain Harvest Index

\section{Introduction}

Rice is a staple and an important food crop around the whole world serving the food requirements of more than half of the world population. A major part of rice production is produced and consumed in Asia (Fageria 2001). With the ever increasing population its production should necessarily rise by more than $60 \%$ in the coming three decades to fulfill the hunger demands. Unfortunately, rice and other grain production have been observed to be stagnant for more than ten years raising a serious concern owing to a wide gap between the increased demand and decreased supply of food grains. Development of fertilizer re-

* Corresponding author; E-mail: shankhdhar.sc@rediffmail.com 
sponsive varieties in the green revolution (Ladha and Reddy 2003), competition for $\mathrm{N}$ uptake between crop plants and nitrifying and denitrifying bacteria, volatilization, leaching of N (Galloway et al. 2008) has led to the $\mathrm{N}$ exhaustion from the farmland and generated the necessity of judicious rates of the fertilizer use in rice production. Moreover, it is among the most limiting macronutrient in rice production, due to its high requirement of about $1 \mathrm{~kg}$ of nitrogen to produce $15-20 \mathrm{~kg}$ of grains. Lowland varieties of tropics in particular are more susceptible to $\mathrm{N}$ deficiency with a recovery efficiency of 30 to $50 \%$ of the N supplied (De Datta 1986; Fageria and Baligar 2001). Since fertilizers are considered to be quite expensive it becomes highly essential to apply doses that would prove not only appropriate but economical as well. In general crop plants are inefficient at nitrogen uptake from the soil, with as much as 50 to $75 \%$ of applied $\mathrm{N}$ being left unused by the plants (Pilbeam 1996; Hodge et al. 2000). Though N is crucially needed by plants for their development its excess in soils may have a negative impact on the environment such as contributing to water pollution and the greenhouse effect. Therefore, next to fertilization of soils selection of $\mathrm{N}$ use efficient crops must be an important target so as to gain a production of higher yields with a reduced $\mathrm{N}$ application per hectare. It would add to the reduction in costs of farmers input invested from his hard earned money (Khurana et al. 2007).

$\mathrm{N}$ use, Grain yield and $\mathrm{N}$ accumulation, $\mathrm{N}$ in aboveground plant biomass, $\mathrm{N}$ harvest index, and grain $\mathrm{N}$ accumulation are the key indicators of $\mathrm{N}$ use efficiency (Huggins and Pan 2003). As to have a cumulative impact in the development of cereal based cropping system less amount of fertilizer and N use efficient (NUE) crop plants should be chosen. However, most of the studies have been carried out under the same environmental conditions those concerning with $\mathrm{N}$ use efficiency and yield under different environmental conditions are still limited. In the light of above consideration an attempt has been made in this present study to evaluate the variability of yield and NUE under different $\mathrm{N}$ levels.

\section{Materials and Methods}

The present study was performed during rainy seasons of 2008 and 2009 at the N. E. Borlaug Crop Research Centre, G. B. Pant University of Agriculture and Technology Pantnagar, Uttarakhand, India. Geographically, the site lies in the tarai plains about $30 \mathrm{~km}$ southwards of foothills of Shivalik range of Himalayas at $29^{\circ} \mathrm{N}$ latitude, $79^{\circ} 29^{\prime} \mathrm{E}$ longitudes and at an altitude 243.8 meter above the sea level. The soil of the Experimental site was silty clay loam in texture ( $32 \%$ sand, $39 \%$ silt and $29 \%$ clay), alkaline in reaction $(\mathrm{pH} 7.3)$, low in organic carbon ( $0.36 \%$ ) having $200 \mathrm{~kg} \mathrm{ha}^{-1}$ available N. The experimental field was laid out in split plot design with three replications. The different rice genotypes, namely Vasumati, Kasturi, Tulsi and Krishna Hamsa, were utilized for evaluation under N levels $(0,50,100$ and $200 \mathrm{~kg} / \mathrm{ha} \mathrm{N})$. Chlorophyll content was determined in fresh leaves at flowering stage by using a method described by Hiscox and Isralesham (1979). Biological and grain yield from each plot was recorded after harvesting and finally expressed as t/ha.N content of different plant parts was determined at maturity by the method of micro-Kjeldahl digestion according to A.O.A.C. (1970). Agronomical and physiological N use efficiency was calculated according to Quanbao et al. (2007). ANUE can be expressed 
as difference in grain yield between that recorded at $\mathrm{N}$ application and without $\mathrm{N}$ application per unit of N application. Similarly PNUE can be expressed as difference in grain yield between that recorded at $\mathrm{N}$ application and without $\mathrm{N}$ application per unit of difference in total plant $\mathrm{N}$ uptake between that observed at $\mathrm{N}$ application and without $\mathrm{N}$ application. The statistical analysis of data for all the parameters was carried out with analysis of variance for split plot design. The means were tested at $P>0.05$ using SPSS- 16 software. The letters indicate significance level for comparison of means and their interactive effect.

\section{Results}

\section{Plant height}

The increment in plant height was in congruence with increasing $\mathrm{N}$ fertilizer application during both the years 2008 and 2009 at active tillering (Table 1). During 2008, maximum increase (with respect to control) in plant height was observed at $\mathrm{N}_{50}(10.03 \%)$ for Krishna Hamsa while, during 2009 it was recorded for Tulsi (30.81\%) at $\mathrm{N}_{200}$. However, amongst the treatments $\mathrm{N}_{200}$ during 2008 and $\mathrm{N}_{100}$ during 2009 were most effective in improving the plant height of the rice plants in different genotypes.

\section{Tiller number}

Tiller number was significant in response to different $\mathrm{N}$ doses during both the years for all the genotypes (Table 1). At maximum tillering Vasumati had the highest number of tillers (10.73 during 2008 and 9.33 during 2009) at $\mathrm{N}_{200}$. During 2008, percent increase in number of tillers (40.91\% in Kasturi, 39.13\% in Krishna Hamsa, 39.13\% in Tulsi and 50.00\% in Vasumati) was highest at $\mathrm{N}_{200}$ in all the genotypes. Whereas during 2009, maximum increase in the number of tillers was at $\mathrm{N}_{200}$ in Tulsi, Vasumati and Kasturi; while for the genotype Krishna Hamsa maximum increase in tiller number was observed at $\mathrm{N}_{100}$. Hence, a direct correlation in the production of number of tillers and amount of the applied $\mathrm{N}$ fertilizer can be deduced.

\section{Leaf area index}

Leaf area index was directly affected by different levels of $\mathrm{N}$ fertilizer application. It increased consistently with the increasing $\mathrm{N}$ levels during both the years. Highest LAI at flowering was recorded for the genotype Krishna Hamsa at $\mathrm{N}_{200} 6.85$ during 2008 showing an increase of $41.6 \%$ and 6.50 during 2009 with an increase of $35.2 \%$ in comparison to control (Table 1). Amongst the treatments, all the genotypes were found to be most responsive at the treatment $\mathrm{N}_{200}$ showing maximum increase in LAI in comparison to the control during both the years. However, primary and secondary branches were not significantly affected by N treatments during both the years (Table 1). During 2008, Krishna Hamsa showed maximum primary as well as secondary branches, i.e. 11.33 and 39.33, respectively, at $\mathrm{N}_{200}$. While during 2009, Krishna Hamsa and Vasumati showed maximum 


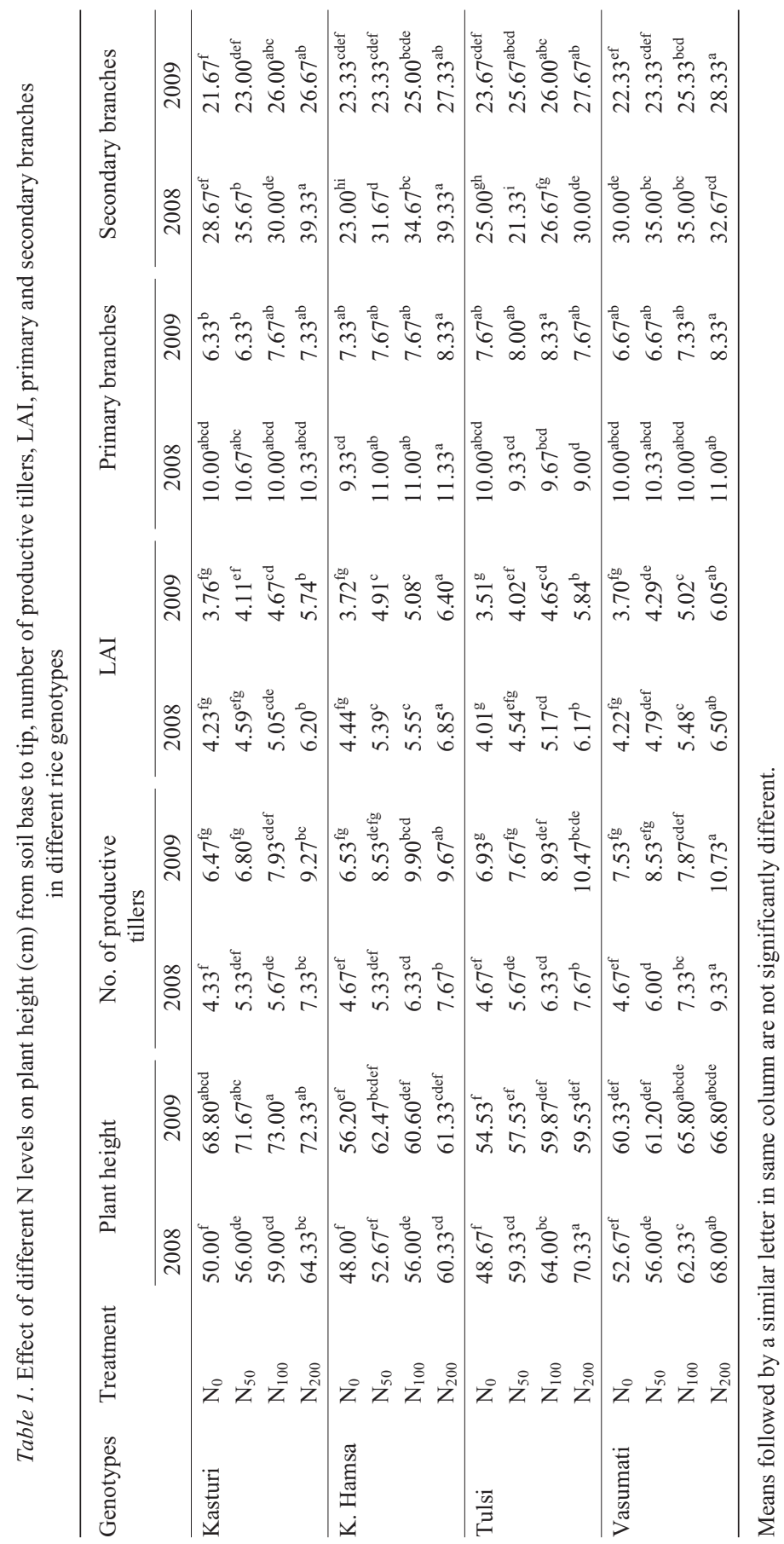


primary branches, i.e. 8.33 at $\mathrm{N}_{200}$ and highest secondary branches were observed for Vasumati (28.33) at $\mathrm{N}_{200}$.

\section{Chlorophyll content}

Chlorophyll a, chlorophyll b and total chlorophyll content (Table 2) was significantly affected by $\mathrm{N}$ fertilizer application. In comparison to control total chlorophyll content was higher in all the treatments (viz. $\mathrm{N}_{50}, \mathrm{~N}_{100}$ and $\mathrm{N}_{200}$ ) for all the genotypes during both the years. In 2008 an enhancement of $27.9-39.5 \%$ over the control was observed in chlorophyll a in different genotypes while chlorophyll $\mathrm{b}$ showed an enhancement ranging from $15.1-39.5 \%$ in different genotypes. However, during 2009 this increase ranged from $21.3-38.6 \%$ for chlorophyll a and from $32.9-40.8 \%$ for chlorophyll $\mathrm{b}$ in different genotypes in comparison to the control. During 2008, $\mathrm{N}_{200}$ was most responsive in influencing the increase in total chlorophyll content with different genotypes showing an increment of $36.46 \%$ in Kasturi, $48.98 \%$ in Vasumati, $40.17 \%$ in Krishna Hamsa and $38.57 \%$ in Tulsi at flowering. Similarly during 2009, highest chlorophyll content was observed for the treatment $\mathrm{N}_{200}$ for all the genotypes under study in comparison to the control. Similarly in case of chlorophylls $\mathrm{a}$ and $\mathrm{b}$ treatment $\mathrm{N}_{200}$ was found to be most responsive in all the four genotypes during both the years.

Table 2. Effect of different $\mathrm{N}$ levels on $\mathrm{a}, \mathrm{b}$ and total chlorophyll content $\left(\mathrm{mg} \mathrm{g}^{-1} \mathrm{FW}\right)$ at flowering in different rice genotypes

\begin{tabular}{|c|c|c|c|c|c|c|c|}
\hline \multirow[t]{2}{*}{ Genotypes } & \multirow[t]{2}{*}{ Treatment } & \multicolumn{2}{|c|}{$\begin{array}{l}\text { Chlorophyll a content } \\
\quad\left(\mathrm{mg} \mathrm{g}^{-1} \mathrm{FW}\right)\end{array}$} & \multicolumn{2}{|c|}{$\begin{array}{l}\text { Chlorophyll b content } \\
\quad\left(\mathrm{mg} \mathrm{g}^{-1} \mathrm{FW}\right)\end{array}$} & \multicolumn{2}{|c|}{$\begin{array}{l}\text { Total chlorophyll content } \\
\left(\mathrm{mg} \mathrm{g}^{-1} \mathrm{FW}\right)\end{array}$} \\
\hline & & 2008 & 2009 & 2008 & 2009 & 2008 & 2009 \\
\hline \multirow[t]{4}{*}{ Kasturi } & $\mathrm{N}_{0}$ & $1.028^{\mathrm{g}}$ & $1.13^{\mathrm{de}}$ & $0.399^{\operatorname{lm}}$ & $0.45^{\mathrm{a}}$ & $1.42^{\mathrm{e}}$ & $2.17^{\mathrm{f}}$ \\
\hline & $\mathrm{N}_{50}$ & $1.295^{\mathrm{ef}}$ & $1.38^{\mathrm{cd}}$ & $0.486^{\mathrm{ef}}$ & $0.57^{\mathrm{bc}}$ & $1.78^{\mathrm{cd}}$ & $2.30^{\text {cde }}$ \\
\hline & $\mathrm{N}_{100}$ & $1.386^{\mathrm{de}}$ & $1.38^{\mathrm{cd}}$ & $0.569^{\mathrm{c}}$ & $0.67^{\mathrm{cd}}$ & $1.95^{\mathrm{b}}$ & $2.46^{\text {cde }}$ \\
\hline & $\mathrm{N}_{200}$ & $1.427^{\mathrm{cd}}$ & $1.84^{\mathrm{ab}}$ & $0.577^{\mathrm{c}}$ & $0.76^{\mathrm{de}}$ & $2.00^{\mathrm{b}}$ & $3.10^{\mathrm{a}}$ \\
\hline \multirow[t]{4}{*}{ K. Hamsa } & $\mathrm{N}_{0}$ & $1.002^{\mathrm{g}}$ & $1.39^{\mathrm{de}}$ & $0.383^{\mathrm{m}}$ & $0.55^{\mathrm{b}}$ & $1.38^{\mathrm{e}}$ & $2.16^{\text {cde }}$ \\
\hline & $\mathrm{N}_{50}$ & $1.284^{\mathrm{ef}}$ & $1.60^{\mathrm{bc}}$ & $0.445^{\mathrm{hi}}$ & $0.62^{\mathrm{c}}$ & $1.72^{\mathrm{d}}$ & $2.43^{b c}$ \\
\hline & $\mathrm{N}_{100}$ & $1.348^{\mathrm{de}}$ & $1.62^{\mathrm{bc}}$ & $0.472^{\text {fg }}$ & $0.71^{\mathrm{d}}$ & $1.82^{\mathrm{cd}}$ & $2.55^{\mathrm{b}}$ \\
\hline & $\mathrm{N}_{200}$ & $1.522^{\mathrm{bc}}$ & $1.88^{\mathrm{b}}$ & $0.502^{\mathrm{de}}$ & $0.82^{\text {de }}$ & $2.02^{\mathrm{b}}$ & $3.10^{\mathrm{a}}$ \\
\hline \multirow[t]{4}{*}{ Tulsi } & $\mathrm{N}_{0}$ & $0.983^{g}$ & $0.81^{\mathrm{f}}$ & $0.433^{\mathrm{ij}}$ & $0.74^{\mathrm{d}}$ & $1.41^{\mathrm{e}}$ & $1.33^{\mathrm{g}}$ \\
\hline & $\mathrm{N}_{50}$ & $1.227^{\mathrm{e}}$ & $0.96^{\mathrm{ef}}$ & $0.460^{\mathrm{gh}}$ & $0.92^{\mathrm{e}}$ & $1.68^{\mathrm{d}}$ & $1.74^{\mathrm{fg}}$ \\
\hline & $\mathrm{N}_{100}$ & $1.405^{\mathrm{d}}$ & $0.97^{\mathrm{e}}$ & $0.505^{\mathrm{d}}$ & $1.04^{\mathrm{ef}}$ & $1.91^{\mathrm{bc}}$ & $1.78^{\mathrm{f}}$ \\
\hline & $\mathrm{N}_{200}$ & $1.521^{b c}$ & $1.03^{\mathrm{de}}$ & $0.510^{\mathrm{d}}$ & $1.18^{\mathrm{f}}$ & $2.03^{\mathrm{b}}$ & $1.92^{\mathrm{ef}}$ \\
\hline \multirow[t]{4}{*}{ Vasumati } & $\mathrm{N}_{0}$ & $1.087^{\mathrm{g}}$ & $1.36^{\mathrm{cd}}$ & $0.412^{\mathrm{kl}}$ & $0.49^{\mathrm{ab}}$ & $1.49^{\mathrm{e}}$ & $2.01^{\mathrm{de}}$ \\
\hline & $\mathrm{N}_{50}$ & $1.537^{\mathrm{b}}$ & $1.51^{\mathrm{c}}$ & $0.424^{\mathrm{jk}}$ & $0.62^{\mathrm{c}}$ & $1.96^{\mathrm{d}}$ & $2.37^{\mathrm{bcd}}$ \\
\hline & $\mathrm{N}_{100}$ & $1.786^{\mathrm{a}}$ & $2.00^{\mathrm{ab}}$ & $0.598^{\mathrm{b}}$ & $0.67^{\mathrm{cd}}$ & $2.38^{\mathrm{a}}$ & $2.98^{\mathrm{a}}$ \\
\hline & $\mathrm{N}_{200}$ & $1.798^{\mathrm{a}}$ & $2.03^{\mathrm{a}}$ & $0.681^{\mathrm{a}}$ & $0.75^{\mathrm{de}}$ & $2.47^{\mathrm{a}}$ & $3.10^{\mathrm{a}}$ \\
\hline
\end{tabular}

Means followed by a similar letter in same column are not significantly different. 


\section{Biological yield and grain yield}

The observations recorded for biological yield showed positive correlation with the plant vegetative growth parameters as well as different $\mathrm{N}$ levels (Fig. 1). Among all the genotypes Krishna Hamsa showed maximum increase in biological yield with an increase of $47.11 \%$ at $\mathrm{N}_{200}$ in comparison to control, during 2008. However, during 2009, highest increase in biological yield was recorded for Tulsi ( $45.45 \%$ increase) at $\mathrm{N}_{100}$ as compared to control.

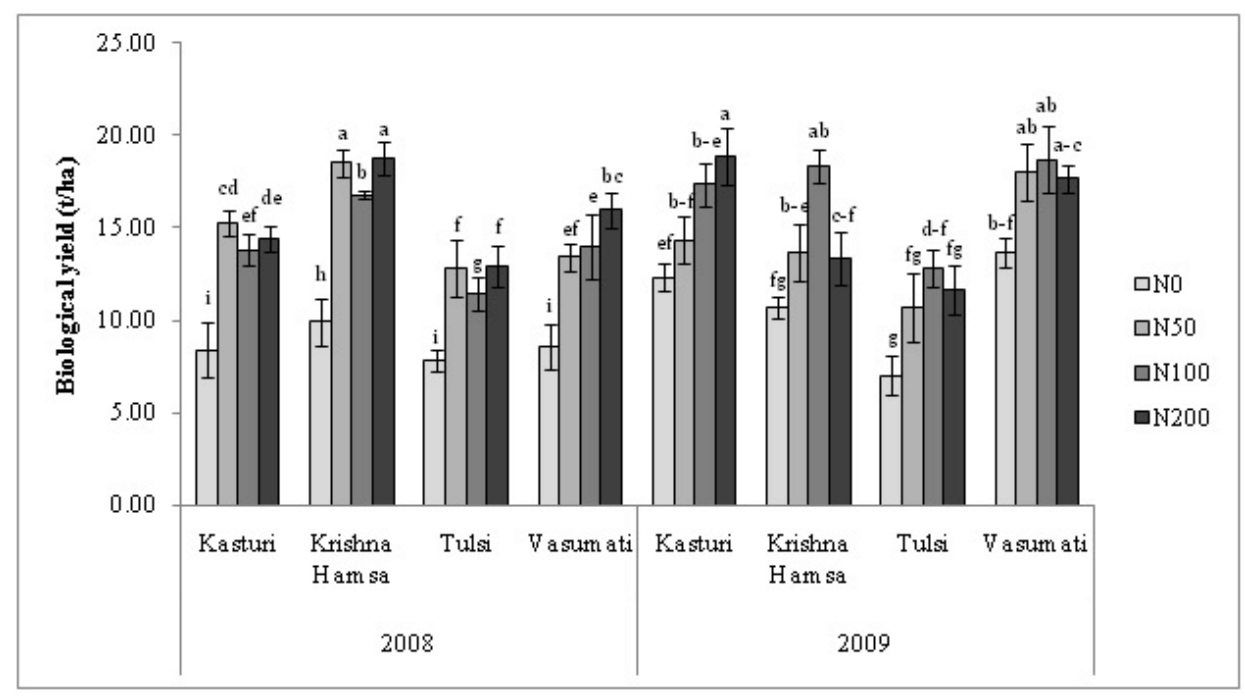

Figure 1. Effect of different $\mathrm{N}$ levels on biological yield $\left(\mathrm{t} \mathrm{ha}^{-1}\right)$ in different rice genotypes. Vertical bars represent \pm standard deviation. Means followed by a similar letter in same column are not significantly different

During both the years, Krishna Hamsa showed maximum increase in grain yield (Fig. 2) in comparison to all other genotypes in response to different N treatments. During 2008, Krishna Hamsa showed maximum increase in grain yield at $\mathrm{N}_{50}$, i.e. $48.57 \%$ as compared to control. However, during 2009 grain yield was found to be increased with increasing $\mathrm{N}$ levels and was found to be maximum at $\mathrm{N}_{100}$ level for most of the genotypes, with highest grain recorded for the genotype Krishna Hamsa $\left(7.15 \mathrm{tha}^{-1}\right)$ showing an increment of $44.5 \%$ in comparison to control. It was observed that biological and grain yield of all the genotypes were significantly affected with increasing $\mathrm{N}$ levels.

\section{Grain harvest index}

The influence of different N levels on GHI (Grain Harvest Index) is shown in Fig. 3. It was observed in 2008 that GHI was found to be maximum for Krishna Hamsa, i.e. 31.56 at $\mathrm{N}_{50}$ level with the increase of $3.64 \%$ as compared to control and minimum for Vasumati, 


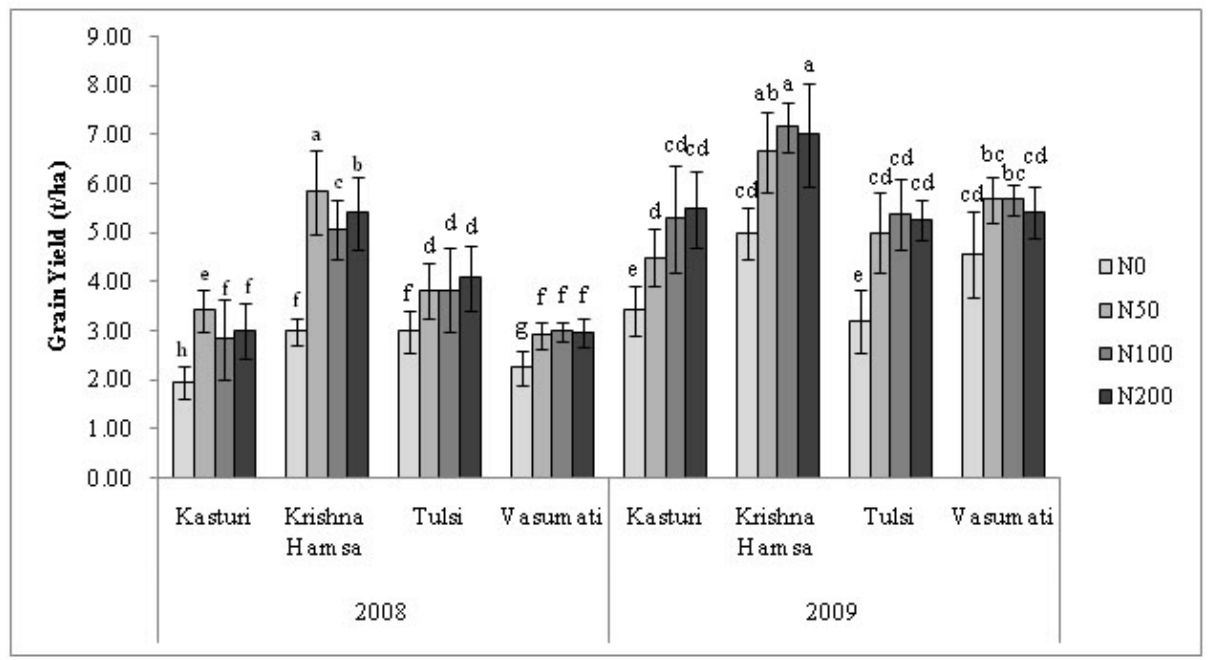

Figure 2. Effect of different $\mathrm{N}$ levels on grain yield $\left(\mathrm{t} \mathrm{ha}^{-1}\right)$ in different rice genotypes.

Vertical bars represent \pm standard deviation. Means followed by a similar letter in same column are not significantly different

i.e. $18.51 \%$ at $\mathrm{N}_{200}$ level (Fig. 3). In 2009 maximum GHI was also observed for Krishna Hamsa, i.e. $54.52 \%$ at $\mathrm{N}_{200}$ level with the increase of $13.48 \%$ when compared to control and minimum for Kasturi, i.e. $28.57 \%$ at $\mathrm{N}_{50}$ level of $\mathrm{N}$ application.

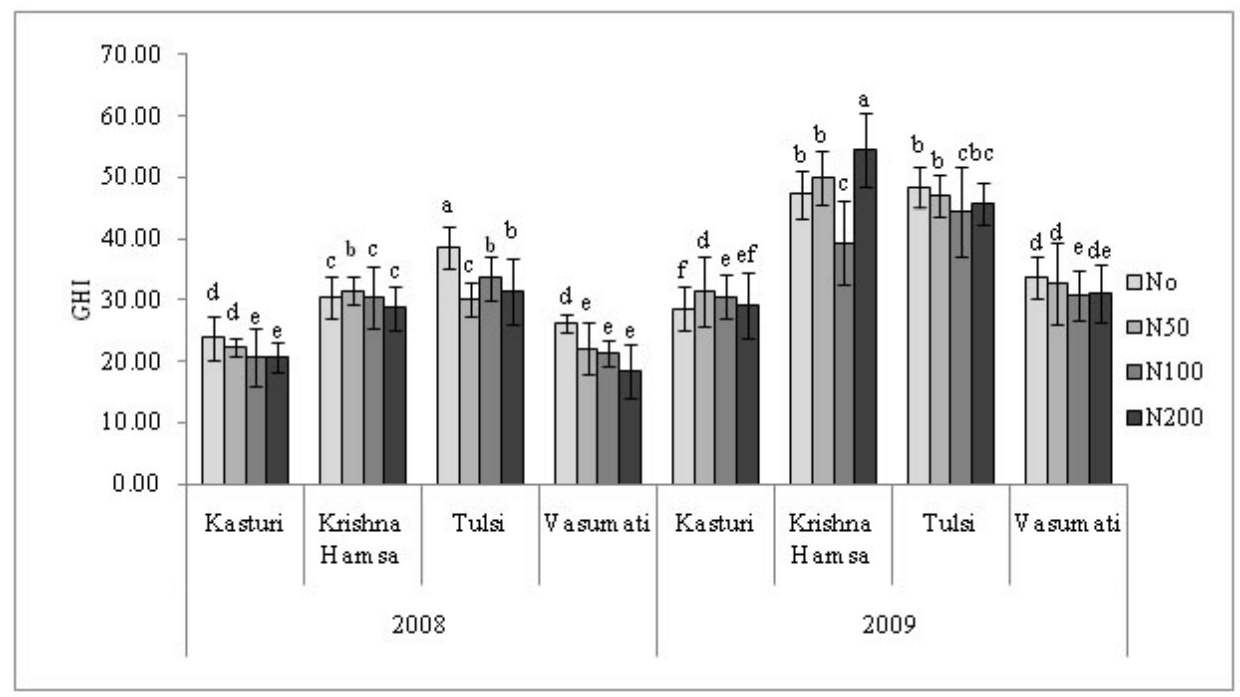

Figure 3. Effect of different $\mathrm{N}$ levels on Grain Harvest Index in different rice genotypes. Vertical bars represent \pm standard deviation. Means followed by a similar letter in same column are not significantly different 


\section{Grain $N$ content}

The effect of different $\mathrm{N}$ levels on $\mathrm{N}(\%)$ in grains is presented in Table 3 . The percentage of $\mathrm{N}$ content was positively correlated to increasing doses of $\mathrm{N}$ application. The rice plants treated with $\mathrm{N}_{200}$ level of $\mathrm{N}$ had the highest grain $\mathrm{N}$ content values. The maximum grain $\mathrm{N}$ percentage was found for the genotype Krishna Hamsa, i.e. $1.65 \%$ exhibiting an increment of $27.27 \%$ as compared to control when treated with $\mathrm{N}_{200}$ level in 2008 . During 2009 as well, it was highest for Krishna Hamsa, i.e. $1.66 \%$ with an enhancement of $23.82 \%$ with respect to control.

Table 3. Effect of different $\mathrm{N}$ levels on total nitrogen uptake $\left(\mathrm{kg} \mathrm{ha}^{-1}\right)$, nitrogen content $(\mathrm{N} \%)$ in grains, physiological and agronomical nitrogen use efficiency in different rice genotypes

\begin{tabular}{|c|c|c|c|c|c|c|c|c|c|}
\hline \multirow[t]{2}{*}{$\begin{array}{l}\text { Geno- } \\
\text { types }\end{array}$} & \multirow[t]{2}{*}{ Treatment } & \multicolumn{2}{|c|}{$\begin{array}{l}\text { Total nitrogen } \\
\text { uptake }\end{array}$} & \multicolumn{2}{|c|}{$\begin{array}{l}\text { Nitrogen content } \\
(\mathrm{N} \%) \text { in grains } \\
\text { efficiency }\end{array}$} & \multicolumn{2}{|c|}{$\begin{array}{l}\text { Physiological } \\
\text { nitrogen use } \\
\text { efficiency }\end{array}$} & \multicolumn{2}{|c|}{$\begin{array}{l}\text { Agronomical } \\
\text { nitrogen use }\end{array}$} \\
\hline & & 2008 & 2009 & 2008 & 2009 & 2008 & 2009 & 2008 & 2009 \\
\hline \multirow[t]{4}{*}{ Kasturi } & $\mathrm{N}_{0}$ & $67.54^{f}$ & $76.47^{\mathrm{d}}$ & $1.19^{\mathrm{f}}$ & $1.25^{\mathrm{f}}$ & - & - & - & - \\
\hline & $\mathrm{N}_{50}$ & $127.29^{d}$ & $94.51^{\mathrm{cd}}$ & $1.47^{\mathrm{bc}}$ & $1.33^{\mathrm{d}}$ & $30.66^{\mathrm{a}}$ & $32.65^{\mathrm{a}}$ & $25.79^{\mathrm{ab}}$ & $21.60^{\mathrm{abc}}$ \\
\hline & $\mathrm{N}_{100}$ & $134.31^{\mathrm{c}}$ & $129.94^{\mathrm{bc}}$ & $1.45^{\mathrm{bc}}$ & $1.50^{\mathrm{b}}$ & $21.52^{\mathrm{de}}$ & $22.83^{\mathrm{b}}$ & $17.23^{\mathrm{cd}}$ & $18.76^{\text {bcd }}$ \\
\hline & $\mathrm{N}_{200}$ & $140.44^{\mathrm{bc}}$ & $148.88^{\mathrm{a}}$ & $1.56^{\mathrm{b}}$ & $1.59^{\mathrm{ab}}$ & $21.11^{\mathrm{de}}$ & $23.87^{b}$ & $10.50^{\mathrm{de}}$ & $10.31^{\text {cde }}$ \\
\hline \multirow[t]{4}{*}{ K. Hamsa } & $\mathrm{N}_{0}$ & $76.63^{\mathrm{e}}$ & $67.03^{\mathrm{d}}$ & $1.20^{\mathrm{ef}}$ & $1.26^{\mathrm{f}}$ & - & - & - & - \\
\hline & $\mathrm{N}_{50}$ & $149.40^{\mathrm{b}}$ & $88.77^{\mathrm{d}}$ & $1.33^{\mathrm{cd}}$ & $1.30^{\mathrm{de}}$ & $32.66^{\mathrm{a}}$ & $34.93^{\mathrm{a}}$ & $31.82^{\mathrm{a}}$ & $47.00^{\mathrm{ab}}$ \\
\hline & $\mathrm{N}_{100}$ & $149.35^{b}$ & $136.85^{\mathrm{b}}$ & $1.52^{\mathrm{bc}}$ & $1.50^{\mathrm{b}}$ & $25.09^{b c}$ & $28.59^{b}$ & $21.96^{\mathrm{bc}}$ & $28.50^{\mathrm{abc}}$ \\
\hline & $\mathrm{N}_{200}$ & $190.75^{\mathrm{a}}$ & $110.4^{\mathrm{c}}$ & $1.65^{\mathrm{a}}$ & $1.66^{\mathrm{a}}$ & $21.42^{\text {de }}$ & $20.93^{\mathrm{cd}}$ & $9.77^{\mathrm{de}}$ & $10.15^{\mathrm{cde}}$ \\
\hline \multirow[t]{4}{*}{ Tulsi } & $\mathrm{N}_{0}$ & $64.69^{f}$ & $44.99^{\mathrm{e}}$ & $1.20^{\mathrm{ef}}$ & $1.29^{\mathrm{e}}$ & - & - & - & - \\
\hline & $\mathrm{N}_{50}$ & $113.13^{\mathrm{de}}$ & $76.54^{\mathrm{d}}$ & $1.30^{\mathrm{cd}}$ & $1.44^{\mathrm{bc}}$ & $31.86^{\mathrm{a}}$ & $29.43^{\mathrm{a}}$ & $30.18^{\mathrm{a}}$ & $36.60^{\mathrm{a}}$ \\
\hline & $\mathrm{N}_{100}$ & $110.26^{\mathrm{de}}$ & $95.05^{\mathrm{cd}}$ & $1.57^{\mathrm{b}}$ & $1.49^{\mathrm{bc}}$ & $24.89^{c}$ & $24.28^{\mathrm{b}}$ & $14.03^{\mathrm{de}}$ & $21.83^{\mathrm{abc}}$ \\
\hline & $\mathrm{N}_{200}$ & $128.70^{\mathrm{d}}$ & $88.46^{\mathrm{d}}$ & $1.64^{\mathrm{a}}$ & $1.52^{\mathrm{b}}$ & $23.53^{\mathrm{cd}}$ & $22.81^{\mathrm{b}}$ & $11.01^{\mathrm{de}}$ & $10.33^{\text {cde }}$ \\
\hline \multirow[t]{4}{*}{ Vasumati } & $\mathrm{N}_{0}$ & $71.86^{\text {ef }}$ & $86.98^{\mathrm{d}}$ & $1.09^{\mathrm{f}}$ & $1.28^{\mathrm{e}}$ & - & - & - & - \\
\hline & $\mathrm{N}_{50}$ & $121.32^{\mathrm{de}}$ & $118.59^{c}$ & $1.34^{\mathrm{cd}}$ & $1.33^{\mathrm{d}}$ & $27.83^{b}$ & $25.46^{\mathrm{b}}$ & $27.10^{\mathrm{ab}}$ & $22.40^{\mathrm{abc}}$ \\
\hline & $\mathrm{N}_{100}$ & $131.54^{\mathrm{c}}$ & $137.88^{b}$ & $1.54^{\mathrm{b}}$ & $1.48^{\mathrm{c}}$ & $22.75^{\mathrm{cd}}$ & $21.54^{\mathrm{bc}}$ & $16.21^{\mathrm{cd}}$ & $11.33^{\text {cde }}$ \\
\hline & $\mathrm{N}_{200}$ & $154.53^{\mathrm{b}}$ & $137.76^{\mathrm{b}}$ & $1.55^{\mathrm{b}}$ & $1.57^{\mathrm{ab}}$ & $19.05^{\mathrm{e}}$ & $14.03^{\mathrm{d}}$ & $7.19^{\mathrm{ef}}$ & $4.35^{\mathrm{de}}$ \\
\hline
\end{tabular}

Means followed by a similar letter in same column are not significantly different.

\section{Nitrogen use efficiency}

Agronomic $\mathrm{N}$ use efficiency was defined as the ratio of grain yield with $\mathrm{N}$ application minus grain yield without $\mathrm{N}$ application to $\mathrm{N}$ application and was used to describe the capability of yield increase per kilogram pure N. With increase in $\mathrm{N}$ application, ANUE of all genotypes was found to be decreased significantly. It indicated that the capability of yield increase per kilogram pure $\mathrm{N}$ declined remarkably with increasing $\mathrm{N}$ application. Physiological $\mathrm{N}$ use efficiency (defined as the ratio of yield increased with $\mathrm{N}$ application to total plant $\mathrm{N}$ uptake) increased with $\mathrm{N}$ application and reflected the utilization of absorbed $\mathrm{N}$ by rice plant. PNUE of all genotypes decreased significantly with increase in $\mathrm{N}$ application. Agronomical and physiological $\mathrm{N}$ use efficiency decreased with increasing $\mathrm{N}$ levels during both the years (Table 3). During 2008, agronomically as well as physiologically 
Krishna Hamsa proved to be most efficient in using applied N with ANUE value recorded to be 31.82 at $\mathrm{N}_{50}$ and PNUE recorded to be (30.18). While, during 2009, highest ANUE was recorded for Tulsi (35.93) at $\mathrm{N}_{50}$ and PNUE was highest for Kasturi (32.66) at $\mathrm{N}_{50}$.

\section{Discussion}

Plant height might be increased due to enhanced vegetative growth with more $\mathrm{N}$ supply to plant that increase in plant height with increased application of N. Similar findings have also been reported by (Manzoor et al. 2006). Likewise, tiller number per square meter also increased with the increase in $\mathrm{N}$ content absorbed by the crop plant in the earlier investigations (Yoshida et al. 1972; Galloway et al. 2008). Hence in the present investigation increased in tiller number was due to the increase in the availability, absorption and accumulation of $\mathrm{N}$ by the rice plants. The results of present study are supported by the findings of Yosef (2012) in which maximum tiller number (27.6) was observed under $150 \mathrm{~kg} / \mathrm{ha} \mathrm{N}$ fertilizer and minimum tiller, i.e. (22.8) was obtained for $50 \mathrm{~kg} / \mathrm{ha} \mathrm{N}$ fertilizer.

$\mathrm{N}$ is also very important to yield because of its key role in cell division. If cell division is stopped, the leaf area decreases and crop plant thereby loses its potential to produce an adequate yield (Gholizadeh et al. 2009). Similarly Khalifa et al. (2008) found that both economic and biological yields were closely correlated with optimum leaf area index (LAI) of plant community of different rice cultivars. Therefore, higher LAI is an important trait for achieving higher yields. An increase in the LAI was reported in response to the $\mathrm{N}$ fertilizer application thereby suggesting an increase in the yield of the rice plants. Similarly, high LAI in response to high N application has been reported by Hirose and Oikawa (2012). In present investigation, total chlorophyll content was found to be higher in response to all the treatments of $\mathrm{N}$, which was found in accordance with Li et al. (2012) who showed that in rice seedlings chlorophyll content decreased by $8 \%$ when fed with low $\mathrm{N}$ and increased by $12 \%$ when fed with high $\mathrm{N}$. Very close link between chlorophyll and $\mathrm{N}$ content has been proved earlier by Amaliotis et al. (2004). Crop plants grown on soils with sufficient amounts of available $\mathrm{N}$ showed a rapid growth with a healthy green color. $\mathrm{N}$ deficiency results in plants of poor color and quality (Cen et al. 2006). In similar experiments Bojović and Marković (2009) also reported that $\mathrm{N}$ being a structural element of chlorophyll affects formation of chloroplasts and accumulation of chlorophyll in them.

Biological yield depends on many factors like leaf area, chlorophyll content, total photosynthetic efficiency of the crop cover, with all of these factors being affected by increase in the $\mathrm{N}$ levels. Therefore, in present investigation increase in leaf area and total chlorophyll content directly correlates with the increase in the yield of the rice plants treated with high doses of N. Similar response was observed by Tari et al. (2009). Moreover, rice fed with high $\mathrm{N}$ produces high grain yield, because $\mathrm{N}$ application stimulates the growth of superficial roots and increases grain yield more efficiently, mainly because of improved grain filling (Yang and Sun 1990). This has been found in accordance with and hence justifies the higher yield observed the rice genotype Krishna Hamsa, which showed higher biological as well as grain yields. In a similar study same effect of $\mathrm{N}$ application has been observed on grain yield by Wei et al. (2012) and Li et al. (2012). The GHI (Grain 
Harvest Index) is a useful index in evaluating treatment effects on partitioning photo assimilates to grain during reproductive growth stages and varies for different cultivars and environmental conditions. Thus it is considered as an important trait for improving grain yield in cereals (Fageria 2007, 2009).

The GHI values of modern crop cultivars are commonly higher than old traditional cultivars for major field crops (Ludlow and Muchlow 1990). Upland rice yield can be significantly improved with developing genotypes of higher grain harvest index (George et al. 2002). Furthermore, higher $\mathrm{N}$ use efficiency has also been observed in rice cultivars with high harvest index (Bufogle et al. 1997). It was observed that $\mathrm{N}$ content in grains in directly proportional to $\mathrm{N}$ supply. These results are confirmed by (Kaushal et al. 2010) who also reported that $\mathrm{N}$ content in grains increased significantly with the increase in $\mathrm{N}$ level from 90 to $120 \mathrm{~kg} \mathrm{~N} \mathrm{ha}^{-1}$ through highest value was recorded at $150 \mathrm{~kg} \mathrm{~N} \mathrm{ha}^{-1}$.

Decreased in ANUE and PNUE indicated that capability of yield increase per kg pure $\mathrm{N}$ declined remarkably with increasing $\mathrm{N}$ application. Excessive use of $\mathrm{N}$ fertilizers resulted in decrease in physiological $\mathrm{N}$-use efficiency and causes serious environmental pollution reported by Jiang et al. (2005). The uptake of $\mathrm{N}$ by different rice varieties increases with increasing the rates of $\mathrm{N}$ application, but it reduces the $\mathrm{N}$ use efficiency. It was observed that with increasing $\mathrm{N}$ application, ANUE and PNUE of all genotypes were decreased significantly. It indicated that the capability of increase in yield per kilogram pure $\mathrm{N}$ declined remarkably with increasing $\mathrm{N}$ application. A similar result has been reported by ( $\mathrm{Li}$ et al. 2012), who showed that lower PNUE under high N supply will finally result in a lower NUE. Similar results were also reported by Quanbao et al. (2007) and Feng et al. (2011) in their studies.

Since $\mathrm{N}$ is closely related to the growth of plants, appropriate application of $\mathrm{N}$ results in the increase in vegetative growth and ultimately in higher yield of the plants. The application of $\mathrm{N}$ to the rice plants has proved to be an important strategy that can be used to improve plant growth as well as yield attributes of rice plants. It is important to monitor the $\mathrm{N}$ status of rice and thereby to adjust the rate of $\mathrm{N}$ fertilization in order to increase $\mathrm{N}$ use efficiency and yield. Hence, evaluation of doses of $\mathrm{N}$-fertilizer application is important because, not only it is cost effective but it is an important issue for soil pollution. Based on the results of this study it can be concluded that maximum grain yield of rice was obtained with the application of $100 \mathrm{~kg} \mathrm{ha}^{-1} \mathrm{~N}$. Plant growth like LAI, and yield component like panicle number significantly and positively associated with grain yield.

\section{Acknowledgement}

The authors are highly grateful to AICRP, ICAR New Delhi, India for financial support during the period of this study. 


\section{References}

A.O.A.C. Association of Official Agricultural Chemists 1970. Official Method of Analysis. Kjeldahl Method. Edn. 11. Washington DC, USA, 934 pp.

Amaliotis, D., Therios, I., Karatissiou, M. 2004. Effect of nitrogen fertilization on growth, leaf nutrient concentration and photosynthesis in three peach cultivars. ISHS. Acta Horticulturae 449:36-42.

Bojović, B., Marković, A. 2009. Correlation between nitrogen and chlorophyll content in wheat (Triticum aestivum L.). Kragujevac J. Sci. 31:69-74.

Bufogle, A., Bollich, P.K., Kovar, J.L., Macchiavelli, R.E., Lindau, C.W. 1997. Rice variety differences in dry matter and nitrogen accumulation as related to plant stature and maturity group. J. Plant Nutri. 20:1203-1224.

Cen, H., Shao, Y., Song, H., He, Y. 2006. Nondestructive estimation of rape nitrogen status using SPAD chlorophyll meter. Proc. $8^{\text {th }}$ Int. Conf. on Signal Processing. IEEE Xplore Press, Beijing, China, pp. 16-20. DOI: 10.1109/ICOSP.2006.344481.

De Datta, S.K. 1986. Improving nitrogen fertilizer efficiency in lowland rice in tropical Asia. Fert. Res. 9:171-186.

Fageria, N.K. 2001. Nutrient management for improving upland rice productivity and sustainability. Commun. Soil Sci. Plant Analysis 32:2603-2629.

Fageria, N.K. 2007. Yield physiology of rice. J. Plant Nutri. 30:843-879.

Fageria, N.K. 2009. The Use of Nutrients in Crop Plants. CRC Press, New York, USA.

Fageria, N.K., Baligar, V.C. 2001. Lowland rice response to nitrogen fertilization. Commun. Soil Sci. Plant Analysis 32:1405-1429.

Feng, C.J., Yan, J.H., Bai, L.Y., Bo, D.T., Xing, C.W. 2011. Methods on identification and screening of rice genotypes with high nitrogen efficiency. Rice Sci. 18:127-135.

Galloway, J.N., Townsend, A.R., Erisman, J.W., Bekunda, M., Cai, Z., Freney, J.R., Martinelli, L.A., Seitzinger, S.P., Sutton, M.A. 2008. Transformation of the nitrogen cycle: Recent trends, questions, and potential solutions. Sci. 320:889-892.

George, T., Magbanua, R., Garrity, D.P., Tubana, B.S., Quiton, J. 2002. Rapid yield loss of rice cropped successively in aerobic soil. Agron. J. 94:981-989.

Gholizadeh, A., Amin, M.S.M., Anuar, A.R. 2009. Evaluation of spad chlorophyll meter in two different rice growth stages and its temporal variability. Eur. J. Sci. Res. 37:591-598.

Hirose, T., Oikawa, S. 2012. Mean residence time of leaf number, area, mass, and nitrogen in canopy photosynthesis. Oecologia 169:927-937.

Hiscox, J.D., Isralesham, G.F. 1979. A method for extraction of chlorophyll from leaf tissue without maceration. Can. J. Bot. 57:1332-1334.

Hodge, A., Robinson, D., Fitter, A. 2000. Are micro-organisms more effective than plants at competing for nitrogen? Trends Plant Sci. 5:304-308.

Huggins, D.R., Pan, W.L. 2003. Key indicators for assessing nitrogen use efficiency in cereal-based agro ecosystems. J. Crop Prod. 8:157-185.

Jiang, L.G., Dong, D.F., Gan, X.Q., Wei, S.Q. 2005. Photosynthetic efficiency and nitrogen distribution under different nitrogen management and relationship with physiological N-use efficiency in three rice genotypes. Plant and Soil 271:321-328.

Kaushal, A.K., Rana, N.S., Singh, A., Sachin, Neeraj, Srivastav, A. 2010. Response of levels and split application of nitrogen in green manured wetland rice (Oryza sativa L.). Asian J. Agri. Sci. 2:42-46.

Khalifa, A.A.B.A., Misra, A.N., Salem, K.M. 2008. Effect of leaf cutting on physiological traits and yield of two rice cultivars. Afr. J. Plant Sci. 2:147-150.

Khurana, H.S., Phillips, S.B., Dobermann, A., Sidhu, A.S., Peng, S. 2007. Performance of site-specific nutrient management for irrigated, transplanted rice in northwest India. Agron. J. 99:1436-1447.

Ladha, J.K., Reddy, R.P. 2003. Nitrogen fixation in rice system: State of knowledge and future prospects. Plant and Soil 252:151-167.

Li, Y., Yang, X., Ren, B., Shen, Q., Guo, S. 2012. Why nitrogen use efficiency decreases under high nitrogen supply in rice (Oryza sativa L.) seedlings. J. Plant Growth Regul. 31:47-52.

Ludlow, M.M., Muchlow, R.C. 1990. A critical evaluation of traits for improving crop yields in water-limited environments. Adv. Agron. 43:107-153.

Cereal Research Communications 43, 2015 
Manzoor, Z., Awan,T.H., Zahid., M.A., Faiz, F.A. 2006. Response of rice crop (super basmati) to different nitrogen levels. J. Anim. Pl. Sci. 16:1-2.

Pilbeam, C.J. 1996. Effect of climate on recovery of crop and soil of N-15 labelled fertilizer applied to wheat. Fert. Res. 45:209-215.

Quanbao, Y.E., Hongcheng, Z., Haiyan, W., Ying, Z., Benfu, W., Ke, X., Zhongyang, H., Qigen, D., Ke, X 2007. Effects of nitrogen fertilizer on nitrogen use efficiency and yield of rice under different soil conditions. Front. Agri. China. 1:30-36.

Tari, D.B., Pirdashti, H.A., Nasiri, M. 2009. Investigation some agronomical traits of rice under different transplanting dates, planting spaces and nitrogen fertilization in north of Iran. World Appl. Sci. J. 6:1021-1027.

Wei, D., Cui, K., Ye, G., Pan, J., Xiang, J., Huang, J., Nie, L. 2012. QTL mapping for nitrogen-use efficiency and nitrogen-deficiency tolerance traits in rice. Plant Soil 359:281-295.

Yang, X., Sun, X. 1990. Effects of $\mathrm{NH}_{4}{ }^{+}-\mathrm{N}$ and $\mathrm{NO}^{3}-\mathrm{N}$ topdressing on the nutrition of hybrid and conventional rice varieties at late growth stage. Acta Agr. Nucleatae Sinica 4:75-79.

Yosef, T.S. 2012. Effect of nitrogen and phosphorus fertilizer on growth and yield rice (Oryza sativa L.). Int. J. Agro. Plant Prod. 12:579-584.

Yoshida, S., Cock, J.H., Parao, F.T. 1972. Physiological aspects of grain yield. Annu. Rev. Plant Physiol. 23:437-464. 